\title{
PENINGKATKAN PENGETAHUAN MASYARAKAT TENTANG MANAJEMEN PERAWATAN HIPERTENSI: PENGABDIAN KEPADA MASYARAKAT
}

\author{
Yunita Dwi Anggreni ${ }^{1^{*}}$, Fauzan Alfikrie ${ }^{2}$, Wahyu Kirana ${ }^{3}$ \\ ${ }^{1-3}$ STIKes Yarsi Pontianak \\ Email Korespondensi: yunitaanggreini@gmail.com \\ Disubmit: 09 September 2021 Diterima: 23 Desember $2021 \quad$ Diterbitkan: 02 Januari 2022 \\ DOI: https://doi.org/10.33024/jkpm.v1i1.5454
}

\begin{abstract}
ABSTRAK
Hipertensi merupakan penyakit tidak menular yang menjadi salah satu penyebab utama kematian. Hipertensi dapat menyebabkan penyakit serius lainnya seperti penyakit stroke, penyakit jantung, penyakit ginjal dan lain-lain. Penderita hipertensi kebanyakan tidak menyadari bahwa mereka memiliki tekanan darah yang tinggi. Umumnya diketahui saat melakukan pemeriksaan kesehatan atau dalam kondisi kesehatan yang buruk. Tujuan pengabdian kepada masyarakat untuk meningkatkan pengetahuan masyarakat tentang manjemen hipertensi. Metode palaksanaan pengabdian kepada masyarakat adalah penyuluhan tentang hipertensi pada penderita hipertensi di Wilayah UPT Puskemas Gang Sehat Kota Pontianak. Hasil pengabdian kepada masyarakat didapatkan adanya peningkatan pengetahuan masyarakat tentang manajemen hipertensi. Pengetahuan merupakan dasar dalam merubah perilaku seseorang menjadi lebih sehat.
\end{abstract}

Kata Kunci: Edukasi, Hipertensi

\section{ABSTRACT}

Hypertension is a non-communicable disease which is one of the main causes of death. Hypertension can cause other serious diseases such as stroke, heart disease, kidney disease and others. Most people with hypertension do not realize that they have high blood pressure. It is generally discovered during a medical examination or is in poor health. The purpose of community service is to increase public knowledge about hypertension management. The method of implementing community service is counseling about hypertension in hypertension sufferers in the UPT Puskemas Gang Sehat area, Pontianak City. The results of community service showed an increase in public knowledge about hypertension management. Knowledge is the basis in changing one's behavior to be healthier.

Keywords: Education, Hypertension 


\section{PENDAHULUAN}

Hipertensi merupakan penyakit tidak menular yang menjadi salah satu penyebab utama kematian prematur di dunia. Organisasi kesehatan dunia (World Health Organization/WHO) mengestimasikan saat ini prevalensi hipertensi secara global sebesar 22\% dari total penduduk dunia. Dari sejumlah penderita tersebut, hanya kurang dari seperlima yang melakukanupaya pengendalian terhadap tekanan darah yang dimiliki. Wilayah Afrika memiliki prevalensi hipertensi tertinggi sebesar $27 \%$. Asia Tenggara berada di posisi ke3 tertinggi dengan prevalensi sebesar $25 \%$ terhadap total penduduk. WHO juga memperkirakan 1 di antara 5 orang perempuan diseluruh dunia memiliki hipertensi. Jumlah ini lebih besar diantara kelompok laki-laki, yaitu 1 diantara 4 (WHO, 2019).

Hasil Riskesdas 2018 menunjukkan angka prevalensi hipertensi pada penduduk > 18 tahun berdasarkan pengukuran secara nasional sebesar $34,11 \%$. Prevalensi ini lebih tinggi dibandingkan prevalensi pada tahun 2013 sebesar 25,8\%. Urutan pertama dengan jumlah kasus hipertensi terbanyak adalah Kalimantan Selatan dengan jumlah kasus 44,13\%. Sedangkan Kalimantan Barat berada diurutan ke-5 dengan jumlah kasus hipertensi yaitu 36,9\% (Kemenkes RI, 2019). Berdasarkan Data Dinas Kesehatan pada tahun 2018, prevalensi hipertensi di Kota Pontianak sebesar 31.737 kasus, di tahun 2019 meningkat 47.125 kasus hal ini merupakan jumlah tertinggi di Kalimantan Barat. Berdasarkan wilayah paling banyak kasus hipertensi, jumlah tertinggi yaitu puskesmas UPTD Puskesmas Pontianak Selatan (Gang Sehat) yang terletak di Kecamatan Pontianak Selatan dengan jumlah 13.804 kasus. Hasil studi pendahuluan jumlah kunjungan penderita hipertensi di Puskesmas Gang Sehat pada masa pandemic mengalami penurunan. Menurut data rekam medik puskemas, jumlah kunjungan layanan hipertensi perhari 10-15 orang dengan jumlah pasien yang berkunjung sekitar 30 orang perhari.

Peningkatan jumlah hipertensi tidak lepas dari faktor resiko yang mendasarinya. Faktor resiko seseorang dapat mengalami hipertensi apabila mengkonsumsi asupan garam berlebih, mengalami stres, obesitas dan faktor dari pembuluh darah. Selain itu faktor genetik juga meningkatkan resiko seseorang mengalami hipertensi (Smeltzer et al, 2013). Selain faktor resiko tersebut, peningkatan kasus hipertensi dapat disebabkan oleh manajemen safety obat hipertensi yang tidak sesuai prinsip pengobatan hipertensi yang berdampak pada tekanan darah yang tidak terkontrol. Menurut Suprapti et al, (2014) kebanyakan pasien hipertensi banyak mengalami dampak kesehatan serius saat tidak mencapai target tekanan darah yang direkomendasikan.

Pengobatan hipertensi tidak boleh terputus hanya karena pasien telah merasa sembuh. Hal ini memicu tekanan darah tidak terkontrol dan diketahui setelah mengalami perburukan. Hasil wawancara kepada kepala puskesmas terhadap layanan hipertensi di puskesmas wilayahnya semua pasien hipertensi mendapat obat antihipertensi dan diberikan edukasi untuk kontrol ulang. Namun, masih banyak penderita hipertensi tidak melakukan kontrol ulang dikarenakan merasa sembuh atau tidak mengetahui pentingnya kontrol ulang. Peneliti melakukan studi pendahuluan pada empat penderita hipertensi. Hasil wawancara didapatkan data:

"klo merasa sudah sembuh obat ndk diminum lagi” ... (p1 45 tahun) 
"biasanya obat diminum, tapi kalau sakit dah ilang, berenti minum obat (p2 40 tahun)

"jarang lah kontrol ke puskesmas, mane nak kontrol ke puskemas kalau ndk ada keluhan, apalagi masa sekarang takut mau ke puskesmas" (p3 47 tahun)

"dirumah mana ada tensi, kalau ngerasa sakit kepala minum jak obat captopril, kalau habis beli agik ke apotik, tunjukkan jag bekas obatnya pandai apotik ngasi yang sama” ... (p4 49 tahun)

Permasalahan hipertensi yang terus meningkat berdasarkan hasil wawancara dapat disimpulkan yaitu pengetahuan yang rendah tentang hipertensi, pengetahuan yang rendah tentang kontrol tekanan darah, pengetahuan yang rendah tentang manajemen obat-obatan penderita hipertensi dan kurangnya pengetahuan tentang dampak hipertensi yang ditimbulkan.

Puskesmas telah melakukan berbagai upaya seperti edukasi, mengingatkan keluarga untuk melakukan kontrol, dan menyelenggarakan posyandu. Namun pada masa pandemic ini, banyak penderita hipertensi yang tidak melakukan kontrol tekanan darah. Hal ini juga di ungkapkan melalui hasil wawancara:

"agak takut ke puskemas, kalau ramai takut virus nyebar" ... (p1 45 tahun)

"ndk pernah ke puskesmas, apa lagi tengah corona ini, (p2 40 tahun)

Hipertensi yang tidak ditangani biasanya muncul gejala ringan, sedang hingga berat, dan bahkan muncul komplikasi serius seperti penyakit stroke, penyakit jantung, hingga gagal ginjal kronik. Seseorang yang menderita hipertensi umumnya mengalami gejala sakit kepala (pusing, migran), epistaksis (mimisan), tinitus (telinga berdenging), palpitasi (berdebar-debar) dan susah tidur. Jika hipertensi tidak ditanganin dengan serius maka akanmenimbulkan komplikasi stroke, gagal jantung, gagal ginjal, infarkmiokard dan disritmia jantung Harding \& Kwong, (2019). Berdasarkan permasalahan yang ditemui diperlukan edukasi untuk meningkatkan pengetahuan masyarakat tentang hipertensi. Tujuan pengabdian kepada masyarakat untuk meningkatkan pengetahuan masyarakat tentang manajemen hipertensi.

\section{MASALAH}

Jumlah kasus hipertensi di wilayah UPT puskesmas Gang Sehat terus meningkat, hal ini dikaitkan dengan jumlah masyarakat yang memeriksakan diri ke pelayanan kesehatan dan kurang pengetahuan masyarakat tentang hipertensi. Kurangnya pengetahuan disebabkan oleh informasi yang diperoleh masyarakat dalam pencegahan hipertensi. Adanya kebingungan masyarakat dalam mencegah dan merawat diri bila terkena hipertensi. Hal ini tampak dari beberapa hasil wawancara dimana masyarakat masih kurang pengetahuannya dalam melakukan pencegahan dan perawatan diri bila terkena hipertensi. 


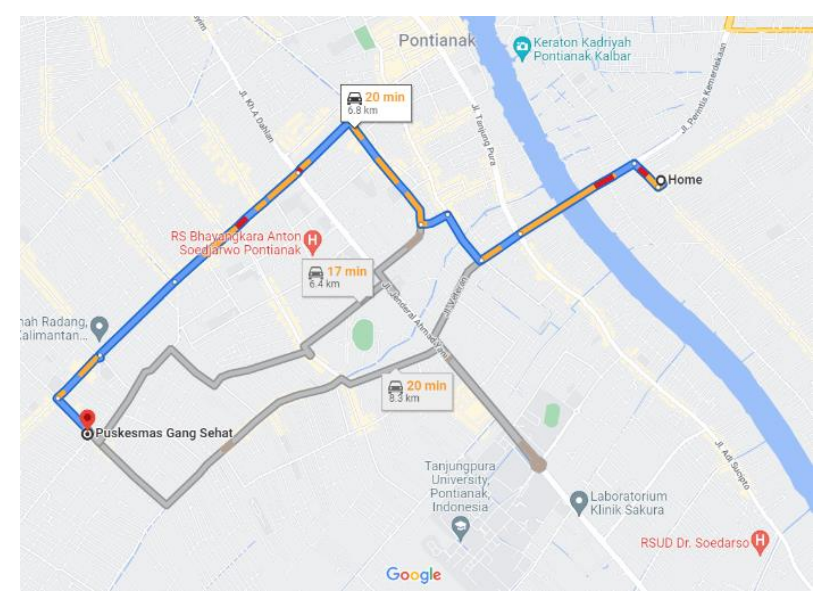

Gambar 1. Peta lokasi dan jarak Institusi ke mitra kerjasama

\section{METODE}

a. Tahap Persiapan

Pada tahapan ini tim pelaksana PKM melakukan beberapa kegiatan yaitu:

1) Administrasi perizinan dan pengumpulan data awal

2) Mengidentifikasi masalah dan mendiskusikannya bersama mitra

3) Menetapkan prioritas masalah

4) Membuat perencanaan bersama mitra sesuai dengan solusi yang telah ditetapkan

b. Tahap Pelaksanaan

Pelaksanaan pengabdian kepada masyarakat dilakukan dengan beberapa tahapan yaitu:

1) Pembukaan oleh moderator

2) Pengukuran pengetahuan sebelum edukadi diberikan

3) Pemberian materi edukasi tentang hipertensi

4) Pengukuran pengetahuan tentang hipertensi setelah edukasi diberikan

5) Penutupan kegiatan

c. Evaluasi

Evaluasi dibagi menjadi tiga bagian yaitu:

1) Evaluasi struktur

Jumlah peserta yang hadir adalah 26 orang, sesuai dengan perencanaan yang telah disusun. Tempat pelaksanaan adalah ruang terbuka setelah dilaksanakan senam sehat bersama tim pelaksana PKM dan UPT Puskesmas Gang Sehat.

2) Evaluasi proses

Pelaksanaan edukasi tentang pencegahan hipertensi dilakukan di halaman depan UPT puskemas Gang Sehat pukul 08.00 sampai dengan 09.00 WIB. Proses pelaksaan berjalan dengan lancar, semua peserta aktif saat berdiskusi tentang pencegahan hipertensi 


\section{HASIL DAN PEMBAHASAN}

Pelaksanaan pengabdian kepada masyarakat dilakukan di UPT Puskesmas Gang Sehat yang diikuti oleh 26 peserta. Hasil pengabdian kepada masyarakat dijelaskan pada tabel 1.

Tabel 1. Distrbusi Frekuensi Pengetahuan Peserta Sebelum dan Setalah Edukasi Pencegahan Hipertensi

\begin{tabular}{cllll}
\hline \multirow{2}{*}{ Kategori } & \multicolumn{2}{c}{ Sebelum } & \multicolumn{2}{c}{ Setalah } \\
\cline { 2 - 5 } & $\mathrm{f}$ & $\%$ & $\mathrm{f}$ & $\%$ \\
\hline Rendah & 15 & 57,7 & 0 & 0 \\
\hline Sedang & 9 & 34,7 & 10 & 38,4 \\
\hline Tinggi & 2 & 7,6 & 16 & 61,6 \\
\hline
\end{tabular}

Hasil pengukuran awal pengetahuan masyarakat tentang pencegahan hipertensi didapatkan data paling banyak masyarakat memiliki pengetahuan yang rendah yaitu $57,7 \%$. Sedangkan setelah diberikan edukasi tentang pencegahan hipertensi diperoleh mayoritas masyarakat memiliki pengetahuan yang tinggi tentang hipertensi. Hasil pengabdian berupa adanya peningkatan pengetahuan masyarakat tentang pencegahan hipertensi dan manajemen hipertensi. Hal ini juga dijelaskan oleh Prasetiya (2015), bahwa edukasi dengan metode ceramah dan tanya jawab dapat meningkatkan pengetahuan masyarakat tentang hipertensi. Hasil penelitian yang sama juga dijelaskan oleh Hamdana (2019), bahwa edukasi tentang hipertensi meningkatkan pengetahuan masyarakat tentang hipertensi. Pengetahuan masyarakat sangat penting dalam upaya pencegahan dan perawatan pada penderita hipertensi. Pengetahuan merupakan hasil tahu yang diperoleh dari penginderaan (Notoatmodjo, 2014).

Edukasi merupakan salah satu cara untuk meningkatkan pengetahan seseorang untuk melakukan tugas dan pekerjaannya. Edukasi bagian yang sangat penting dalam penigkatan pengetahuan. Menurut Notoatmodjo, (2014) pengetahuan yang baik dapat menstitmulus perubahan terkait perilaku individu terhadap kesehatan. Sehingga dengan meningkatnya pengetahuan masyarakat maka diharapkan dapat merubah perilaku masyarakat kearah yang lebih sehat.

Pelaksanaan kegiatan pengabdian kepada masyarakat berjalan dengan baik dan lancar. Hal ini didukung oleh keterlibatan aktif dari mitra pengabdian dalam pelaksanaan edukasi kepada masyarakat. Berikut gambar pelaksanaan kegiatan pengabdian kepada masyarakat di Desa Lemukutan (gambar 1). 

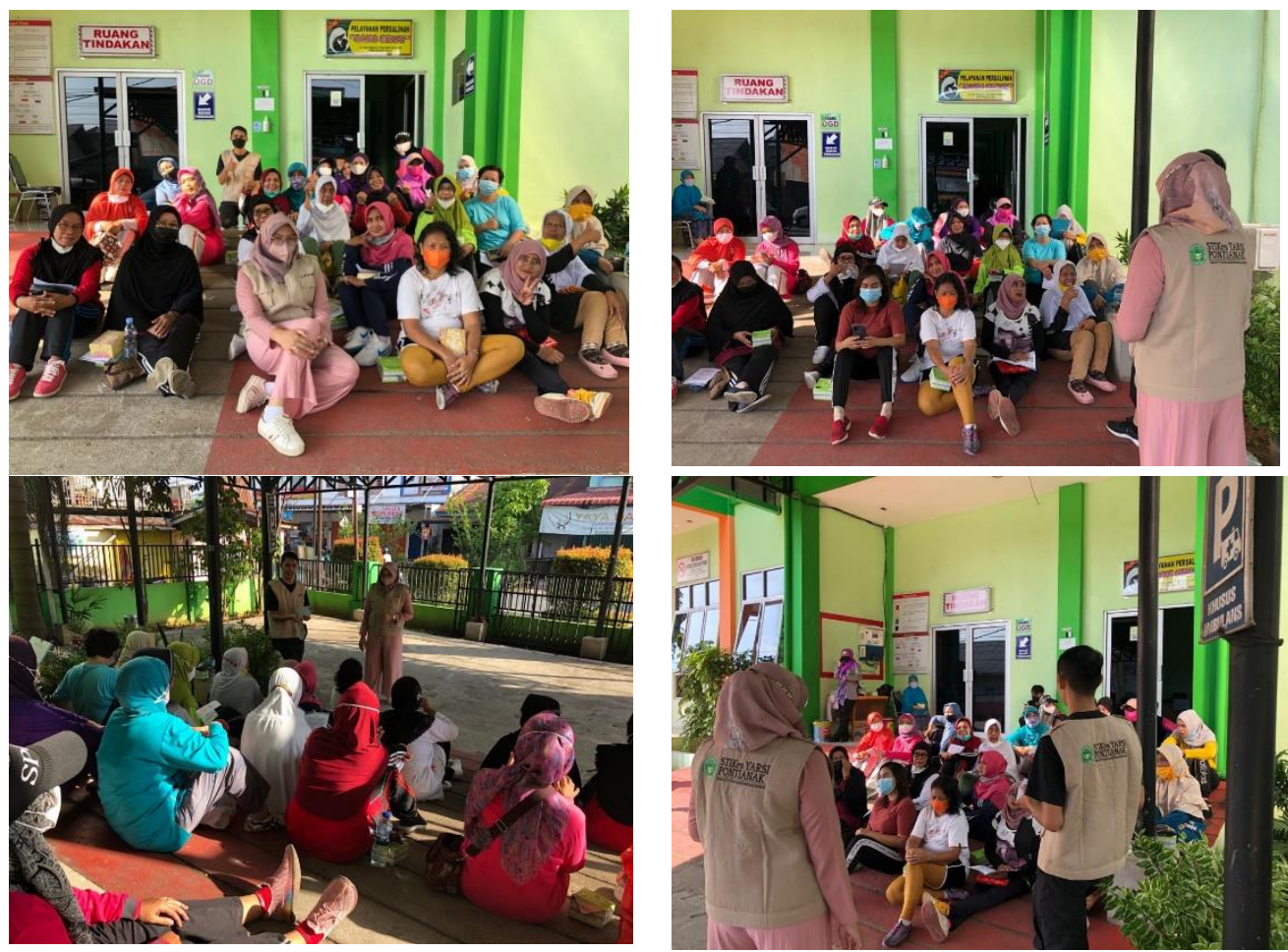

Gambar 1. Kegiatan Pengabdian Kepada Masyarakat

\section{KESIMPULAN}

Berdasarkan hasil pengabdian kepada masyarakat terdapat peningkatan pengetahuan masyarakat setelah diberikan edukasi manajemen hipertensi.

\section{DAFTAR PUSTAKA}

Harding, M.M., Kwong, J., Roberts, D., et al (2019). Lewis 's Medical-Surgical Nursing Assessment and Management of Clinical Problems. $11^{\text {th }}$ Ed. Mosby Elsevier

Kemenkes RI (2019). Infodatin Hipertensi. Diakses di https://pusdatin.kemkes.go.id/resources/download/pusdatin/infodatin /infodatin-hipertensi-si-pembunuh-senyap.pdf

Notoatmodjo S. (2014). Promosi Kesehatan dan Perilaku Kesehatan. Jakarta: PT Rineka Cipta

Prasetya, C.H. (2015). Efektifitas pendidikan kesehatan terhadap peningkatan pengetahuan keluarga tentang hipertensi. Mutiara Medika. 15(1): 67 - 74

Smeltzer, S., Bare, B., Hinkle, J.L., Cheever, K.H. (2010). Brunner \& Sudarth's Text Books of Medical Surgical Nursing 12nd Edition. China: Lippincot Williams \& Wilkins

Suprapti, B., Nilamsari, W.P., Hapsari, P.P., Muzayana, H.A., Firdausi, H. (2014). Permasalahan terkait obat antihipertensi pada pasien usia lanjut di poli geriatri RSUD Dr. Soetomo, Surabaya. Jurnal Farmasi dan IImu Kefarmasian Indonesia, 1(2), 36-41

WHO (2019). Hypertension. Diakses di https://www. who.int/news-room/factsheets/detail/hypertension. 